\title{
The Effect of Fundamental Factors, Sustainability Reporting, and Corporate Governance on Firm Value
}

\author{
Yondrichs, Muliati*, Supriadi Laupe, Arung Gihna Mayapada, Jurana, Ridwan \\ Department of Accounting, Faculty of Economics and Business, Universitas Tadulako, Palu, Indonesia
}

Received September 7, 2021; Revised October 22, 2021; Accepted November 11, 2021

\section{Cite This Paper in the following Citation Styles}

(a): [1] Yondrichs, Muliati, Supriadi Laupe, Arung Gihna Mayapada, Jurana, Ridwan, "The Effect of Fundamental Factors, Sustainability Reporting, and Corporate Governance on Firm Value," Universal Journal of Accounting and Finance, Vol. 9, No. 6, pp. 1503-1509, 2021. DOI: 10.13189/ujaf.2021.090627.

(b): Yondrichs, Muliati, Supriadi Laupe, Arung Gihna Mayapada, Jurana, Ridwan (2021). The Effect of Fundamental Factors, Sustainability Reporting, and Corporate Governance on Firm Value. Universal Journal of Accounting and Finance, 9(6), 1503-1509. DOI: 10.13189/ujaf.2021.090627.

Copyright $(\mathrm{C} 2021$ by authors, all rights reserved. Authors agree that this article remains permanently open access under the terms of the Creative Commons Attribution License 4.0 International License

\begin{abstract}
Purpose: This study aims to analyze the effect of fundamental factors and sustainability reporting on firm value. This study also investigates the moderation effect of corporate governance on the relationship of fundamental factors, sustainability reporting, and firm value. Design/methodology/approach: The population is all companies listed in Indonesia Stock Exchange and indexed in IDX30 throughout 2014-2020. The data are obtained from financial statements, annual reports, and sustainability reports. The analysis method used in this study is panel data regression analysis. Findings: This study shows that profitability and leverage as fundamental factors affect the firm value. This study also found that good corporate governance moderates the effect of the fundamental factors on firm value. However, the sustainability reporting cannot increase the firm value. Research implications: These results verify agency and signaling theories but do not support legitimacy and stakeholder theories. Practical implications: These results confirm that fundamental factors are still the investors' primary concerns about making investment decisions. Originality/value: The novelty of this study lies in highlighting corporate governance as a moderation variable in the relationship of fundamental factors, sustainability reporting, and firm value, which has still not been concluded yet.
\end{abstract}

Keywords Fundamental Factors, Sustainability Reporting, Corporate Governance, Firm Value

\section{Introduction}

Indonesia is the country with the second-highest growth in the composite stock price index in the world after the United States, which reached 125.6\% (https://www.phillip.co.id accessed in 2019). Other data show that the Indonesian capital market has the largest market capitalization and the highest return provider in the ASEAN Capital Market Comparison series, namely $112.38 \%$. However, other facts show that most investors, namely $52.17 \%$ who made transactions through the Indonesia Stock Exchange in 2018, were foreign investors. Meanwhile, the number of domestic investors is still lacking in Indonesia, which is only $0.34 \%$ of the total population. According to foreign investors, most firms in Indonesia are developing, so they promise high returns compared to firms in developed countries. Investors' perceptions of the firm, which are often associated with stock prices, are called firm value. High firm value illustrates investor confidence in the firm that the firm can provide high returns. In general, there are two ways investors determine the value of a firm's shares, namely, technical and fundamental analysis. Technical analysis is generally done for short term investments. Meanwhile, fundamental analysis is carried out by long-term oriented investors. However, Larasati et al. [1], and Permata \& Alkaf [2] stated that fundamental analysis is more appropriate in predicting firm value than technical analysis.

Fundamental analysis is an analysis of accounting 
information summarized in financial statements [3]. Fundamental analysis includes an analysis of the company's financial performance measured by financial ratios, including liquidity, profitability, and leverage ratios [4]. In fundamental analysis, the firm is assumed to be in good condition if these financial ratios show its ability to pay dividends and pay off its debts [5]. Liquidity is one of the fundamental factors that is the main consideration for investors in making investment decisions [6]. The liquidity ratio describes a firm's ability to pay off its short-term debt. Besides the higher the firm's liquidity, the more cash available in the firm to pay dividends to investors. However, too much money can also mean that the firm does not optimally utilize its current assets in obtaining profit. Meanwhile, previous research findings regarding the relationship between liquidity and firm value are still mixed $[7,8]$.

Apart from liquidity, a firm's financial performance is generally seen from its profitability ratio. The better the firm's ability to earn a profit, the investors will perceive the firm is in good condition and can provide high returns $[9,10]$. Therefore, firms with high profitability tend to have high share prices [11]. However, several previous research results revealed that profitability does not have a significant effect on firm value $[10,12]$. Leverage is one of the ratios in the fundamental analysis that represents the firm's capital structure. Leverage shows whether the company is mostly funded through debt or equity. The majority of investors argue that a good firm is a firm that is able to meet its obligations to creditors. Thus, the low leverage of a firm means that the firm can withstand bad conditions. However, previous research findings regarding the relationship between leverage and firm value are also still mixed today.

Therefore, this study examines the effect of fundamental factors and sustainability reporting on firm value with good corporate governance as a moderating variable. The research is started with introduction, followed by the second part developing the hypotheses theoretically and discussing the previous studies. The third section describes the research method. The fourth section discusses the empirical results, and the last section concludes the study. The strength of this paper is the contribution in a growing awareness of Global Reporting Initiative -based sustainability reporting among the firms. Using the basis of ten formulated hypotheses, the empirical evidence yielded significant results, which explain the driving factors behind sustainability reporting. Moreover, the results confirmed that sustainability reporting is value relevant. This result is because sustainability report reporting is still voluntary in Indonesia, and the absence of a uniform reporting standard has made the level of disclosure still vary. Overall, the contribution of this study is to theoretically verify agency and signaling theories. More practically, the research provided a theoretical confirmation about fundamental factors as the investors' primary concerns in making investment decisions.

\section{Literature Review and Hypothesis Development}

Liquidity is one of the fundamental factors that illustrate the firm's ability to pay off short-term obligations on time. Investors are eyeing firms that have a high level of liquidity. Research results of Aggarwal \& Padhan [13], Marsha \& Murtaqi [14], Mulyana et al. [15], and Ozlen [16] show that liquidity has a positive relationship with increasing firm value. This result means that a high level of liquidity will indicate that the firm can meet its short-term obligations and has a stable cash flow, thereby attracting investors which impact increasing firm value. Based on this description, the following hypothesis is formulated:

\section{H1: Liquidity partially has a positive and significant effect on firm value.}

Profitability is a ratio that describes the firm's ability to generate profits. The higher the profitability ratio, the better the company shows its ability to earn profits [17]. In fundamental analysis, profitability is very important because it relates to managers' competence and the firm's ability to provide consistent profits [17]. The firm's ability to generate profits is the main concern of investors because it will reflect the level of return and welfare of shareholders, so that when profitability increases, the firm value will also increase $[5,8,14,15,18,19]$. Based on this description, the following hypothesis is formulated:

\section{H2: Profitability partially has a positive and significant effect on firm value.}

The projected capital structure with a debt-to-equity ratio or leverage ratio is an essential indicator in assessing firm fundamentals. Firms with low debt levels reflect solvable conditions, attracting investors who can increase firm value [20]. Firms whose capital is dominated by debt sources indicate unhealthy conditions and financial risks in the future. Investors tend to look for a low leverage ratio to avoid investment risk. Jogiyanto [21], Kusumowardhani [4], Larasati et al. [1], Sadma [22], Pratiwi [10], and Setiadharma \& Machali [23] stated that the lower the leverage ratio, the better its ability to survive in bad conditions, meaning that the firm can still fulfill its obligations to creditors and impact increasing firm value. Based on this description, the following hypothesis is formulated:

\section{H3: Leverage ratio partially has a negative and significant effect on firm value.}

The sustainability report is a report that contains non-financial information from the firm's social and 
environmental activities that enable the company to grow sustainably [24-26]. Firms can disclose this information in a sustainability report disclosure as a form of corporate accountability to the public [27]. Based on the signaling theory point of view, sustainability reports are part of the signal that firms give to the public. Disclosure of information on social and environmental activities is expected to provide a positive signal to investors as a form of legitimacy for firms that also care about their environment [28]. The research results of Budiana \& Budiasih [29], Fatchan \& Trisnawati [30], Kurniawan et al. [31], Kuzey \& Uyar [32], Latifah \& Luhur [33], and Loh et al. [34] stated a positive relationship between sustainability report disclosure and firm value. Based on this description, the following hypothesis is formulated:

\section{H4: Sustainability report disclosure partially has a positive and significant effect on firm value.}

The practice of good corporate governance through the audit committee's function is expected to increase its focus on striving for a liquid firm financial condition [35]. In this case, the audit committee plays a role in assisting the board of commissioners in supervising the reporting process and company accounting policies to improve its financial performance $[36,37]$. The audit committee will motivate management to reduce the amount of short-term debt to maintain liquid financial conditions [38, 39]. Liquid financial information can be used as a positive signal to attract investors and impact increasing firm value. In the concept of signaling theory, it is revealed that companies that implement good corporate governance tend to give positive signals [40]. Based on this description, the following hypothesis is formulated:

\section{H5: Good corporate governance can moderate the relationship between liquidity and firm value.}

The effectiveness of the audit committee's performance in a firm can encourage firm resource users' efficiency through the supervision of an internal control system that can increase profits to increase firm value [41]. The stakeholder theory stated that with good corporate governance, firms tend to strive to fulfill shareholders' welfare [42]. Through good corporate governance, it is hoped that the principal will have a monitoring tool to reduce opportunistic behavior, information asymmetry, moral hazard violations, the emergence of agency costs, and the cost of capital [43]. Based on this description, the following hypothesis is formulated:

\section{H6: Good corporate governance can moderate the relationship between profitability and firm value.}

Investors, as outsiders, cannot directly observe the firm's financial performance. The audit committee's work existence can positively perceive the firm's financial performance, minimizing risk to prevent investors from having fear. In this case, the audit committee's responsibility is to oversee financial statements, oversee external audits, and help management maintain solvable financial performance stability $[44,45]$. If the audit committee functions effectively, then the firm's control will be better and assist management in striving for a stable financial condition with low debt levels [46]. Based on this description, the following hypothesis is formulated:

\section{H7: Good corporate governance can moderate the relationship between leverage and firm value.}

One of the principles of implementing good corporate governance is responsibility, which can be realized by implementing social responsibility and expressing it in a sustainable report [47]. Weiss [48] stated that the disclosure of sustainability report is considered part of the dialogue between firms and stakeholders. For this reason, sustainability reports are an excellent place to start a positive firm image [49]. Good corporate governance practices will encourage firms to disclose social and environmental responsibility activities in their sustainability reports to increase firm value [50]. This statement is reinforced by one of the objectives of good corporate governance, as stated in Forum for Corporate Governance in Indonesia (FCGI), to create added value for all interested parties [51]. Based on this description, the following hypothesis is formulated:

\section{H8: Good corporate governance can moderate the relationship between sustainability report disclosure and firm value.}

\section{Research Method}

This research is a quantitative study that aims to verify the theory. The study population includes companies listed on the Indonesia Stock Exchange and indexed by IDX30. The research period is 2014-2020. The research sample was selected through purposive criteria, namely:

- the firm was never delisted during the study period,

- the firm published financial reports periodically during the study period,

- the firm published sustainability reports based on GRI G4 standards during the study period,

- the firm never experienced a loss during the study period, and

- the firm has complete data during the study period.

The data analysis technique used is regression analysis with moderating variables using panel data that combines time series and cross-section data. The analysis tool used in this study is the Eviews application version 10 . Meanwhile, the operationalization of fundamental factor variables is liquidity using the current ratio, profitability using the return on equity, and leverage using the 
debt-to-equity ratio. Meanwhile, the sustainability report is measured using the sustainability report index, which is analyzed using content analysis. Good corporate governance is operationalized by the size of the audit committee. Lastly, firm value is calculated using the Tobins' Q formula.

\section{Results}

Panel data regression analysis was carried out using the Chow test and the Hausman test to select the three best models among the common effect, fixed effect, and random effect. Based on the test results, it is found that the most appropriate model is used to estimate panel data, namely the fixed effect model as in Table 1.

The value of the coefficient of determination (adjusted $\mathrm{R}$ square) of 0.8635 can be interpreted that the variations in the variable liquidity, profitability, leverage, and sustainability report disclosure can explain the variation in firm value variables by $86.35 \%$. In comparison, the rest $13.65 \%$ is explained by other variables not included in this model's calculation. Based on the results of the panel data regression analysis above, a regression equation was created as follows:

$$
\begin{gathered}
\mathrm{TQ}_{\mathrm{it}}=2.3975+0.3147 \mathrm{CR}_{\mathrm{it}}+16.7027 \mathrm{ROE}_{\mathrm{it}}-3.0167 \mathrm{DER}_{\mathrm{it}} \\
+0.3442 \mathrm{SRD}_{\mathrm{it}}+\epsilon_{\mathrm{it}}
\end{gathered}
$$

Based on the results of the $\mathrm{F}$ test in Table 1, it can be seen that the F-count value of 36.5910 is greater than the F-table value of 2.5027 , and the significance level is smaller than the level of distrust $(0.000<0.05)$. This value means that simultaneously the liquidity variable, profitability, leverage, and sustainability report disclosure have a significant effect on firm value.

The t-count value of the liquidity variable is smaller than the t-table value $(0.8772<1.9944)$, and the significance level is greater than the level of distrust, which is $5 \%(0.3832>0.05)$. This value means that partially the liquidity variable has no significant effect on firm value. Thus, $\mathrm{H} 1$ is rejected.

The t-count value of the profitability variable is greater than the t-table value $(4.4751>1.9944)$. The significance probability value is smaller than the level of distrust, namely $5 \%(0.0000<0.05)$. This value can be interpreted that partially the profitability variable has a positive and significant effect on firm value. Thus, $\mathrm{H} 2$ is accepted. The $\mathrm{t}$-count value of the leverage variable is greater than the $\mathrm{t}$-table value $(-3.0448>1.9944)$, with the $\mathrm{t}$-count being negative, and the significance level is smaller than the distrust level, which is $5 \%(0.0032<0.05)$. This value can be interpreted that partially the capital structure variable has a negative and significant effect on firm value. Therefore, $\mathrm{H} 3$ is accepted.

The t-count value of the sustainability report disclosure variable is smaller than the $t$-table value $(0.1837<1.9944)$, and the significance level is greater than the level of distrust, which is $5 \%(0.8547>0.05)$. This value can be interpreted that partially the sustainability report disclosure variable has no significant effect on firm value. Thus, H4 is rejected.

Table 1. The result of panel data regression analysis

\begin{tabular}{|c|c|c|c|c|}
\hline Variable & Coefficient & Std. Error & t-Statistic & Probability \\
\hline Constant & 2.397595 & 1.737550 & 1.379871 & 0.1718 \\
\hline Liquidity & 0.314665 & 0.358731 & 0.877163 & 0.3832 \\
\hline Profitability & 16.70269 & 3.732373 & 4.475087 & $0.0000^{*}$ \\
\hline Leverage & -3.016726 & 0.990780 & -3.044798 & $0.0032^{*}$ \\
\hline $\begin{array}{c}\text { Sustainability Report } \\
\text { Disclosure }\end{array}$ & 0.344189 & 1.873199 & 0.183744 & 0.8547 \\
\hline \multicolumn{2}{|c|}{ F-count: 36.59103} \\
\hline
\end{tabular}

Table 2. The result of panel least square for moderating variable

\begin{tabular}{|c|c|c|c|c|}
\hline Variable & Coefficient & Std. Error & t-Statistic & Probability \\
\hline Constant & 2.399353 & 1.475603 & 1.626015 & 0.1082 \\
\hline Liquidity*(CG) & 0.129712 & 0.292848 & 0.442932 & 0.6591 \\
\hline Profitability*(CG) & 14.73078 & 2.877223 & 5.119791 & $0.0000^{*}$ \\
\hline Leverage*(CG) & -2.290123 & 0.824013 & -2.779234 & $0.0069^{*}$ \\
\hline $\begin{array}{c}\text { Sustainability Report } \\
\text { Disclosure*(CG) }\end{array}$ & 0.733900 & 1.511754 & 0.485462 & 0.6288 \\
\hline
\end{tabular}


Based on the results of testing the moderating variables using the moderated regression analysis method in Table 2, the following equation can be made:

$$
\begin{gathered}
\mathrm{TQ}_{\mathrm{it}}=2.3994+0.1297 \mathrm{CR}_{\mathrm{it}} \mathrm{GCG}+14.7308 \mathrm{ROE}_{\mathrm{it}} \mathrm{GCG} \\
-2.2901 \mathrm{DER}_{\mathrm{it}} \mathrm{GCG}+0.7339 \mathrm{SRD}_{\mathrm{it}} \mathrm{GCG}+\epsilon_{\mathrm{it}}
\end{gathered}
$$

The interaction between the liquidity variable and good corporate governance shows a significance value of 0.6591 . This value is smaller than the level of distrust, which is $0.6591>0.05$ with a positive coefficient value of 0.1297 . This value can be interpreted that the variable good corporate governance cannot moderate the relationship between liquidity and firm value. Thus, H5 is rejected.

The interaction between the profitability variable and good corporate governance shows a change in the coefficient value of 14.7308 with a significance value of 0.0000 , smaller than the level of distrust, namely 0.05 . This value can be interpreted that the variable good corporate governance can moderate it by strengthening the relationship between profitability and firm value. Therefore, H6 is accepted. The interaction between the leverage variable and good corporate governance shows a significance value of 0.0069 . This value is smaller than the level of distrust, which is $0.0069<0.05$, with a coefficient value that is negative of -2.2901 . This value can be interpreted that the good corporate governance can be moderated by weakening the relationship between leverage and firm value. Thus, H7 is also accepted

The interaction between the sustainability report disclosure variable with good corporate governance shows a significance value of 0.6288 . This value is greater than the level of distrust, namely $0.6288>0.05$ with a coefficient value of 0.7339 . This value can be interpreted that the good corporate governance cannot moderate the relationship between sustainability report disclosure and firm value. Thus, $\mathrm{H} 8$ is rejected.

Overall, the results of this study support signaling theory that a high level of profitability can be considered good news by investors because profitability information reflects the returns that investors will get in the future [52]. The information will attract investors so that the demand for company shares increases and impacts the firm value [53]. This research is in line with previous research conducted by Mulyana et al. [15] and Tahu \& Susilo [54], which stated a positive and significant relationship between profitability through return on equity to firm value.

In terms of sustainability report disclosure, it will not impact increasing firm value as long as implementing social and environmental responsibility is still minimal because the sustainability report does not give a reaction to investors. The results are in line with researches by Carp et al. [55] and Uwuigbe et al. [56] show that disclosure of sustainability report does not affect firm value. The sustainability report is considered more costly than its benefits in increasing firm value because the information generated from the sustainability report does not have a strong potential to help investors predict investment returns. The results are consistent with previous research conducted by Akdogan \& Boyacioglu [57] which stated that good corporate governance could strengthen the relationship between profitability and firm value.

\section{Conclusions}

This study indicates that profitability and leverage are fundamental factors that are the primary considerations for investors in making investment decisions. Meanwhile, liquidity does not represent the effectiveness of management performance, and in fact, it shows that management is not optimizing the use of assets, especially current assets. Meanwhile, sustainability report disclosure is not a determinant of firm value. The results are because sustainability report reporting is still voluntary in Indonesia, and the absence of a uniform reporting standard has made the level of disclosure still vary. This study also reveals that good corporate governance has a significant impact on determining firm value.

Practically, the results imply that improving corporate governance needs to be done in attracting investors, and clarity of regulations related to sustainability report needs to be formulated immediately. The results present the theoretical implications in verifying agency and signaling theories, but do not support legitimacy and stakeholder theories. As practical implications, these results confirm that fundamental factors are still the investors' primary concerns in making investment decisions. As to present the limitations, the results are limited to the IDX 30 company so the interpretation of the results is carried out carefully. Further research is expected to expand the sample, and the variables to examine the effect of fundamental factors, sustainability reporting, and corporate governance on firm value.

\section{REFERENCES}

[1] Citra Larasati, Abdul Rivai, "Effect of Debt to Equity Ratio and Return on Assets on Earnings per Share with Firm Value as a Moderating Variable in Various Industrial Sub-Sector Manufacturing Companies Indonesia," Asian Business Research Journal, vol. 5, pp. 39-47, 2020.

[2] Irma Sari Permata, Fatima Tuzzahara Alkaf, "Analysis of Market Capitalization and Fundamental Factors on Firm Value," Journal of Accounting and Finance Management, vol. 1, no. 1, pp. 59-71, 2020.

[3] Mark P. Taylor, Helen Allen, "The use of Technical Analysis in the Foreign Exchange Market," Journal of international Money and Finance, vol. 11, no. 3, pp. 304-314, 1992. 
[4] Widyarti Kusumowardhani, "Fundamental Factors of Firm Value: Evidence from the Cement Industry in Indonesia," Jurnal Inovasi Ekonomi, vol. 5, no. 1, 2020.

[5] Ayu Diky Winarsari, Sri Handini, "The Influence of Internal and External Factors of the Company on Dividend Policy and firm Value: Study on LQ45 Companies in Indonesia Stock Exchange 2015-2017," Ekspektra: Jurnal Bisnis Dan Mana-jemen, vol. 4, no. 1, pp. 22-34, 2020.

[6] Rui Ma, Hamish D. Anderson, Ben R. Marshall, "International Stock Market Liquidity: A Review," Managerial Finance, vol. 42, no. 2, pp. 118-135, 2016.

[7] Jonathan Batten, Xuan Vinh Vo, "Liquidity and firm Value in an Emerging Market," The Singapore Economic Review, vol. 64, no. 2, pp. 365-376, 2019.

[8] Shakeel Muhammad, Gohar Ali, "The Relationship between Fundamental Analysis and Stock Returns Based on the Panel Data Analysis; Evidence from Karachi Stock Exchange (KSE)," Research Journal of Finance and Accounting, vol. 9, no. 3, pp. 84-96, 2018.

[9] Khuzaini, Dwi Wahyu Artiningsih, Lina Paulina, "Influence of Profitability, Investment Opportunity Set (Ios) Leverage and Dividend Policy on Firm Value in The L Service in Indonesia Stock Exchange," Jurnal Terapan Manajemen dan Bisnis, vol. 3, no. 2, pp. 235-245, 2017.

[10] Ririh Dian Pratiwi, "Do Capital Structure, Profitability, and Firm Size Affect Firm Value?" Jurnal Penelitan Ekonomi dan Bisnis, vol 5, no. 2, pp. 194-202, 2020.

[11] Ardi Paminto Djoko Setyadi Jhonny Sinaga, "The Effect of Capital Structure, Firm Growth and Dividend Policy on Profitability and Firm Value of the Oil Palm Plantation Companies in Indonesia," European Journal of Business and Management, pp. 2222-1905, 2016.

[12] Renly Sondakh, "The Effect of Dividend Policy, Liquidity, Profitability and Firm Size on Firm Value in Financial Service Sector Industries Listed in Indonesia Stock Exchange 2015-2018 Period," Accountability, vol. 8, no. 2, pp. 91-101, 2019.

[13] Divya Aggarwal, Purna Chandra Padhan, "Impact of capital structure on firm value: Evidence from Indian hospitality industry," Theoretical Economics Letters, vol. 7, no. 4, pp. 982-1000, 2017.

[14] Nadya Marsha, Isrochmani Murtaqi, "The Effect of Financial Ratios on firm Value in the Food and Beverage Sector of the IDX," Journal of Business and Management, vol. 6, no. 2, pp. 214-226, 2017.

[15] Ayu Mulyana, Mulia Saputra Zuraida, "The Influence of Liquidity, Profitability and Leverage on Profit Management and its Impact on Company Value in Manufacturing Company Listed on Indonesia Stock Exchange," International Journal of Managerial Studies and Research, vol. 6, no. 1, pp. 8-14, 2018.

[16] Serife Ozlen, "The Effect of Company Fundamentals on Stock Values," European Researcher, no. 3-2, pp. 595-602, 2014.

[17] Michael C. Thomsett, "Mastering Fundamental Analysis," Dearborn Trade Publishing, 1998.

[18] M. Noor Salim, Rina Susilowati, "The Effect of Internal
Factors on Capital Structure and its Impact on Firm Value: Empirical Evidence from the Food and Baverages Industry Listed on Indonesian Stock Exchange 2013-2017," International Journal of Engineering Technologies and Management Research, vol. 6, no. 7, pp. 173-191, 2019.

[19] Idah Zuhroh, "The Effects of Liquidity, Firm Size, and Profitability on the Firm Value with Mediating Leverage," KnE Social Sciences, pp. 203-230, 2019.

[20] Martono, Agus D. Harjito, Menejemen Keuangan (5 ed.), Yogyakarta, BPFE, 2010.

[21] Hartono Jogiyanto, "Teori Portofolio dan Analisis Investasi (7 ed.)," Yogyakarta, BPFE, 2010.

[22] Oki Sadma, "The Role of Environmental-Based 'Green Startup' in Reducing Waste Problem and its Implication to Environmental Resilience," Research Horizon, vol. 1, no. 3, pp. 106-114, 2021

[23] Stephani Setiadharma, M. Machali, "The Effect of Asset Structure and Firm Size on Firm Value with Capital Structure as Intervening Variable," Journal of Business \& Financial Affairs, vol. 6, no. 4, pp. 1-5, 2017.

[24] Tran Quyen, "The Relationship between Green Procurement Practices and Organizational Performance in the Manufacturing Industry of Vietnam," Arthatama, vol. 4, no. 1, pp. 1-16, 2020.

[25] Respati Kurniawan, "Conservation of Indonesian Tropical Forests as the Lungs of the World," Inkalindo Environmental Journal, vol. 1, no. 1, pp. 62-66, 2020.

[26] Endang Sulastri, Evi Satispi Satispi, "The Role of Government Policies in Environmental Management." Research Horizon, vol. 1, no. 3, pp. 86-93, 2021.

[27] Gehan Mousa, Naser T. Hassan, "Legitimacy Theory and Environmental Practices: Short Notes," International Journal of Business and Statistical Analysis, vol. 2, no. 1, 2015.

[28] Wiyadi, Sayekti Endah Retno Meilani, Imanda Firmantyas Putri Pertiwi, Rina Trisnawati, Nor Hazana Abdullah, "Practices of Human Resource Accounting Disclosure: A Comparative Study across ASEAN Countries," Universal Journal of Accounting and Finance, vol. 9, no. 3, pp. 306 315, 2021. DOI: 10.13189/ujaf.2021.090304

[29] Quita Amelia Budiana, I Gusti Ayu Nyoman Budiasih, "Profitabilitas Sebagai Pemoderasi Pengaruh Pengungkapan Sustainability Reporting Pada Nilai Perusahaan Pemenang Indonesian Sustainability Reporting Awards," E-Jurnal Akuntansi, vol. 30, no. 3, pp. 662, 2020

[30] Ilham Nuryana Fatchan, Rina Trisnawati, "Pengaruh Good Corporate Governance pada Hubungan Antara Sustainability Report dan Nilai Perusahaan (Studi Empiris Perusahaan Go Public di Indonesia Periode 2014-2015)," Riset Akuntansi Dan Keuangan Indonesia, vol. 1, no. 1, pp. 25-34, 2018.

[31] Tedy Kurniawan, Hafiez Sofyani, Evi Rahmawati, "Pengungkapan Sustainability Report dan Nilai Perusahan: Studi Empiris di Indonesia dan Singapura," Kompartemen: Jurnal Ilmiah Akuntansi, vol. 16, no. 1, 2018.

[32] Cemil Kuzey, Ali Uyar, "Determinants of Sustainability Reporting and its Impact on Firm Value: Evidence from the 
Emerging Market of Turkey," Journal of Cleaner Production, vol. 143, pp. 27-39, 2017.

[33] La Latifah, S. W., M. Budi Luhur, "Disclosure of Sustainability Report and Moderating of Profitability and its Impact on Firm Value," Journal of Accounting and Business UNS, vol. 17, no. 1, 2017.

[34] Lawrence Loh, Thomas Thomas, Yu Wang, "Sustainability Reporting and Firm Value: Evidence from Singapore-Listed Companies," Sustainability, vol. 9, no. 11, pp. 2112, 2017.

[35] Anisa Kusumawardani, Rizky Yudaruddin, Yanzil Azizi Yudaruddin, "Corporate Governance's Policy on the Impact of Cash Holding in Indonesia," Universal Journal of Accounting and Finance, vol. 9, no. 4, pp. 594-603, 2021. DOI: 10.13189/ujaf.2021.090407

[36] Kee H. Chung, John Elder, Jang-Chul Kim, "Corporate Governance and Liquidity," Journal of Financial and Quantitative Analysis, vol. 45, no. 2, pp. 265-291, 2010.

[37] Muhammad Fakhimuddin, Uswatun Khasanah, Rini Trimiyati, "Database Management System in Accounting: Assessing the Role of Internet Service Communication of Accounting System Information," Research Horizon, vol. 1, no. 3, pp. 100-105, 2021.

[38] Lilis Saputri, Asrori Asrori, "The Effect of Leverage, Liquidity and Profitability on Financial Distress with the Effectiveness of the Audit Committee as a Moderating Variable," Accounting Analysis Journal, vol. 8, no. 1, pp. 38-44, 2019.

[39] Ooi Keong, "Determinants of Intentions to Engage in Sustainability Accounting \& Reporting (SAR) and Moderating Role of Internal Audit Function: The Perspective of Accountants," Arthatama, vol. 4, no. 1, pp. 33-43, 2020.

[40] Brian L. Connelly, S. Trevis Certo, R. Duane Ireland, Christopher R. Reutzel, "Signaling Theory: A Review and Assessment," Journal of Management, vol. 37, no. 1, pp. 39-67, 2011.

[41] Elly Halimatusadiah, Diamonalisa Sofianty, Husnah Nurlaela Ermaya, "Effects of the Implementation of Good Corporate Governance on Profitability," European Journal of Business and Innovation Research, vol. 3, no. 4, pp. 19-35, 2015.

[42] R. Edward Freeman, Jeffrey S. Harrison, Andrew C. Wicks, Bidhan L. Parmar, Simone De Colle, "Stakeholder Theory: The State of the Art," Cambridge University Press, 2010.

[43] Andrew L. Friedman, Samantha Miles, "Stakeholders: Theory and practice," Oxford University Press on Demand, 2006.

[44] Paul Collier, Alan Gregory, "Audit Committee Activity and Agency Costs," Journal of Accounting and Public Policy, vol. 18 , no. 4-5, pp. 311-332, 1999.

[45] Agus Sobar, Asep Deni, Riki Riswandi, Dendi Zainuddin Hamidi, Indra Permadi, "The Effect of Product Turnover on
Company Performance of SMEs," Research Horizon, vol. 1, no. 3, pp. 115-119, 2021.

[46] Septiana, Subowo, "The Effect of Firm Size, Profitability, and Leverage on Intellectual Capital Disclosure with Audit Committee as Moderator," Accounting Analysis Journal, vol. 9, no. 3, pp. 152-158, 2020.

[47] Dwi Susilo, "The Effects of Corporate Social Responsibility to the Corporate Value," Arthatama, vol. 2, no. 2, pp. 85-96, 2018.

[48] Weiss J, "A stakeholder and Issues Management Approach," Mason, USA, Cengage learning, pp. 552, 2015.

[49] Jannati Tangngisalu, M. Mappamiring, Wuryan Andayani, Muhammad Yusuf, Aditya Halim Perdana Kusuma Putra, "CSR and Firm Reputation from Employee Perspective," The Journal of Asian Finance, Economics, and Business, vol. 7, no. 10, pp. 171-182, 2020.

[50] Dwi Nita Aryani, Bernad Engelberd Niron, "Good Corporate Governance on Corporate Social Responsibility with Profitability, Size and Leverage as Moderating Variables (Case Study at Regional Development Banks in Indonesia)," pp. 279-282, 2018.

[51] I. Dewa Made Endiana, "Implementasi Corporate Governance Pada Corporate Social Responsibility Terhadap Nilai Perusahaan," Jurnal Riset Akuntansi (JUARA), vol. 9, no. 1, pp. 92-100, 2019.

[52] Widuri Kurniasari, Yusni Warastuti, "Between CSR and Profitability to Firm Value in Sri-Kehati Index," International Journal of Economic Behavior (IJEB), vol. 5, no. 1, pp. 31-41, 2015.

[53] Dwita Ayu Rizqia, Siti Aisjah Sumiati, "Effect of Managerial Ownership, Financial Leverage, Profitability, Firm Size, and Investment Opportunity on Dividend Policy and Firm Value," Research Journal of Finance and Accounting, vol. 4, no. 11, pp. 120-130, 2013.

[54] Gregorius Paulus Tahu, Dominicius Djoko Budi Susilo, "Effect of Liquidity, Leverage and Profitability to the Firm Value (Dividend Policy as Moderating Variable) in Manufacturing Company of Indonesia Stock Exchange," Research Journal of Finance and Accounting, vol. 8, no. 18, pp. 89-98, 2017.

[55] Mihai Carp, Leontina Păvăloaia, Mihai-Bogdan Afrăsinei, Iuliana Eugenia Georgescu, "Is Sustainability Reporting a Business Strategy for Firm's Growth? Empirical Study on the Romanian Capital Market," Sustainability, vol. 11, no. 3, pp. $658,2019$.

[56] Uwalomwa Uwuigbe, Obarakpo Teddy, Olubukola Ranti Uwuigbe, Ozordi Emmanuel, Osariemen Asiriuwa, Gbenedio Akpevwenoghene Eyitomi, Oluwagbemi Simeon Taiwo, "Sustainability Reporting and Firm Performance: A Bi-Directional Approach," Academy of Strategic Management Journal, vol. 17, no. 3, pp. 1-16, 2018.

[57] Yunus Emre Akdogan, Melek Acar Boyacioglu, "The Effect of Corporate Governance on Firm Performance: A Case of Turkey," International Journal of Critical Accounting, vol. 6, no. 2, pp. 187-210, 2014. 